\title{
Optimal Fixation and Decalcification Methods for Bone Marrow Biopsy
}

\author{
Myung-Sub Choi ${ }^{1}$, Hyunsup Lee ${ }^{1}$, Hyuk-Chul Kwon ${ }^{1}$, Moon-Hwan Bae ${ }^{1}$, Young-Hye Ko ${ }^{1}$, \\ Hee-Jin Kim², Beom-Se Lee ${ }^{2}$, and Bon-Kyung Koo ${ }^{2}$ \\ ${ }^{1}$ Department of Pathology, Samsung Medical Center, Seoul 06351, Korea \\ ${ }^{2}$ Department of Laboratory Medicine, Samsung Medical Center, Seoul 06351, Korea
}

\section{골수생검조직을 위한 최적의 고정 및 탈회 방법}

\author{
최명섭 ${ }^{1}$, 이현섭 ${ }^{1}$, 권혁철 ${ }^{1}$, 배문환 $^{1}$, 고영혜 ${ }^{1}$, 김희진 $^{2}$, 이범세 ${ }^{2}$, 구본경 $^{2}$ \\ 삼성서울병원 ${ }^{1}$ 병리과, ${ }^{2}$ 진단검사의학과
}

\begin{abstract}
A bone marrow biopsy that has undergone decalcification with $10 \%$ nitric acid could not be used for various pathological tests and had extremely limited reproducibility. The fixing solution of each experimental group was differentiated in usage, one solution including acid and the other not. The use of the decalcification solution was separated into either acidic or alkaline (EDTA), and further experiments were conducted with differing time phases. When using a fixing solution and decalcification solution which included acid, the specimens were faulty to the extent that all pathological tests were impossible. However specimens that were processed with an EDTA type decalcification solution did not display a non-specific reaction in EBV ISH and were even able to produce results that were at a level suited to various studies or a pathological diagnosis in the FISH, DNA, RNA tests. By improving the fixing and decalcification of bone marrow biopsy, the study was able to make possible ISH, FISH, DNA tests as well as RNA study, and secured the sensitivity, specificity, and reproducibility of various test methods. The stabilization of various test methods that use bone marrow biopsy contributes to the diagnosis, prognosis, prediction, treatment of the patient and provide guidelines for decision-making.
\end{abstract}

Keywords: Bone marrow biopsy, Decalcification, Fixation, Methods

This is an Open Access article distributed under the terms of the Creative Commons Attribution Non-Commercial License (http://creativecommons.org/licenses/by-nc/4.0) which permits unrestricted non-commercial use, distribution, and reproduction in any medium, provided the original work is properly cited.

Copyright $\odot 2015$ The Korean Society for Clinical Laboratory Science. All rights reserved.
Corresponding author: Hyunsup Lee Department of Pathology, Samsung Medical Center, Seoul 06351, Korea Tel: 82-2-3410-2772

E-mail: hs772.lee@samsung.com

Received: November 1, 2015 Revised $1^{\text {st: }}$ November 16, 2015 Revised 2 ${ }^{\text {nd }}$ : November 23, 2015 Accepted: November 23, 2015

\section{서 론}

병리검사 표본용 조직절편은 적출 직후부터 고정, 탈수, 탈회, 투 명, 포매, 박절, 동결, 탈파라핀, 염색, 봉입까지 전과정에서 화학적, 물리적 영향이 가해진다.

조직처리과정 중 가장 중요한 단계는 고정이며 그 목적은 자가 융해 방지, 부패 방지, 조직의 보존, 조직의 경화, 염색의 매염 효과 를 얻기 위한 것이다(KAUPCLS, 2006).
고정액은 10\% 중성 완충 포르말린 용액, Zenker 용액, Bouin 용 액, Carnoy 용액 등이 있으며 골조직을 고정하기 위해서는 $10 \%$ 중 성 완충 포르말린 용액을 일반적으로 사용한다. 그 이유는 탈회작 용으로 생기는 결체조직의 팽창이 비교적 적기 때문이다(Cotelingam, 2003; Lee 등, 2008).

골조직에는 칼슘이 침착되어 있기 때문에 표본제작을 위해서 사 전에 칼슘을 제거하여 박절하기에 적합하도록 조직을 연화시키는 탈회과정이 필요하다. 
탈회법은 산(acid) 탈회법, 이온교환수지 탈회법, 전기분해 탈회 법, 초음파 탈회법 등이 있다(Witter 등, 2000; Kim 등 2005; Sangeetha 등, 2013).

탈회액은 5 10\% 질산 용액, $10 \%$ 염산 용액, $5 \%$ 개미산 용액, Plank-Rychlo 용액, Morse 용액, EDTA (ehylenediamintetraacetic acid) 용액 등이 있는데 산은 골조직 내 칼슘과 반응하여 용 해성 칼슘 형태로 바뀌며, EDTA는 칼슘이온과 선택적으로 착염하 여 칼슘을 제거하는 특징이 있다(Cotelingam, 2003; Dimenstein, 2008; Lee 등, 2008).

일반적으로 $10 \%$ 질산 용액으로 탈회를 거친 골수생검조직에서 는 미량의 엡스타인-바 바이러스(Epstein-Barr virus, EBV) 양성 혈액종양 환자의 골수 침범 시 진단이 불가능하였으며 다른 분자병 리검사도 불가능하거나 극히 제한적이었다.

본 실험은 삼성서울병원 병리과에서 수행된 2009년도 질 향상 활동 과제이며, 목적은 골수생검조직을 처리하는 다양한 종류의 고 정액과 탈회액 중에서 최적의 고정액, 고정시간, 탈회액, 탈회시간 을 찾고, 고정액 및 탈회액으로 인한 DNA 파괴를 최소화함으로써 각종 분자병리검사의 가능성을 추구하고, 동시에 검사의 재현성을 확보하는데 있다.

\section{재료 및 방법}

\section{1. 실험재료}

본 실험에 사용된 검체는 2009년도에 삼성서울병원에 내원한 환자의 골수생검조직(463건)을 이용하였다.

\section{2. 실험방법}

1) 고정액 및 탈회액 제조에 사용된 시약

시약은 zinc chloride (Z0173; Sigma-Aldrich Co., St Louis, USA), glacial acetic acid (A0033; Samchun Co., Pyeongtaek, Korea), 37\% formalin (F0162; Samchun Co.), sodium phos-

Table 1. Fixation solution

\begin{tabular}{clc}
\hline \multicolumn{1}{c}{ Types } & \multicolumn{1}{c}{ Ingredients } & Contents \\
\hline Acetic acid-zinc & Zinc chloride & $50 \mathrm{~g}$ \\
formalin & Glacial acetic acid & $1.9 \mathrm{~mL}$ \\
& $37 \%$ formalin & $300 \mathrm{~mL}$ \\
& Distilled water & $700 \mathrm{~mL}$ \\
$10 \%$ formalin & Formalin & $100 \mathrm{~mL}$ \\
& Distilled water & $900 \mathrm{~mL}$ \\
$10 \%$ neutral & Sodium phosphate monobasic & $4 \mathrm{~g}$ \\
buffered formalin & Sodium phosphate diabasic & $6.5 \mathrm{~g}$ \\
& Formalin & $100 \mathrm{~mL}$ \\
& Distilled water & $900 \mathrm{~mL}$ \\
\hline
\end{tabular}

phate monobasic (S0909; Samchun Co.), sodium phosphate diabasic (S0893; Samchun Co.), nitric acid (438073; SigmaAldrich Co.), Shandon TBD-1 신속 염산 탈회액(Thermo Fisher Scientific Co., Waltham, USA), EDTA (E5134; Sigma-Aldrich Co.), Trizma base (T6066; Sigma-Aldrich Co.)를 사용하였다 (Table 1, 2).

\section{2) 고정 및 탈회 과정}

실험 방법으로는 고정액은 산 포함 고정액과 산 비포함 고정액 으로 구분하고, 고정시간은 $4,8,24$ 시간으로 나누어 실험하였으며 탈회액은 산성 탈회액, 알칼리성 탈회액(EDTA 계열)으로 구분하 고, 탈회시간은 4, 8, 12, 24, 32, 48시간으로 나누어 실험하였다. 고정액 및 탈회액 조합은 1 단계로 산 포함 고정액과 산성 탈회액, 산 포함 고정액과 알칼리성 탈회액으로, 2 단계는 산 비포함 고정액 과 산성 탈회액, 산 비포함 고정액과 알카리성 탈회액으로, 3 단계 는산 비포함 고정액과 알카리성 탈회액으로 조합하여 실험하였다.

\section{3) 면역 및 분자병리검사를 사용한 검증방법}

검증방법으로 Bond-Max immunohistochemistry stainer (Leica Biosystems Co., Wetzlar, Germany) 기기를 사용한 EBV 동소교잡반응(Epstein-Barr virus by in situ hybridization, EBV ISH), Statspin ThermoBrite slide processing system (Leica Biosystems Co., Wetzlar, Germany) 기기를 사용한 C-MYC 형광 동소교잡반응 (C-MYC fluorescence in situ hybridization, CMYC FISH), GeneAmp 9700 PCR system (Applied Biosystems Co., Waltham, USA) 기기를 사용한 DNA 중합효소연쇄반응(deoxyribonucleic acid polymerase chain reaction, DNA PCR), ABI PRISM 7900HT sequence detection system (Applied Biosystems Co., Waltham, USA) 기기를 사용한 RNA 역전사 실시 간 연쇄 중합반응(ribonucleic acid reverse transcriptase poly-

Table 2. Decalcification solution

\begin{tabular}{clr}
\hline Types & Ingredients & Contents \\
\hline \multirow{2}{*}{$5 \%$ nitric acid } & Nitric acid & $50 \mathrm{~mL}$ \\
& Distilled water & $950 \mathrm{~mL}$ \\
10\% nitric acid & Nitric acid & $100 \mathrm{~mL}$ \\
& Distilled water & $900 \mathrm{~mL}$ \\
$5 \%$ EDTA, pH 8.0 & 0.5 mole EDTA & $200 \mathrm{~mL}$ \\
& Distilled water & $800 \mathrm{~mL}$ \\
$10 \%$ EDTA, pH 8.0 & 0.5 mole EDTA & $400 \mathrm{~mL}$ \\
& Distilled water & $600 \mathrm{~mL}$ \\
Tris/EDTA, pH 9.0 & 0.5 mole EDTA & $100 \mathrm{~mL}$ \\
& 1.0 mole Tris & $10 \mathrm{~mL}$ \\
& Distilled water & $950 \mathrm{~mL}$ \\
\hline
\end{tabular}


merase chain reaction, RNA real-time $\mathrm{PCR}$ )와 같은 분자병리 검 사의 결과에 각 실험군이 미치는 영향을 평가하였다.

검증기준으로는 $\mathrm{EBV}$ 동소교잡반응은 비특이적 반응을 보이는 위양성, C-MYC 형광동소교잡반응은 정상 형광신호정보, DNA 중 합효소연쇄반응은 뚜렷한 염색대, RNA 실시간 연쇄 중합반응은 260/280 ratio (260/280 values of 1.8 and 2.0, respectively)를 기준으로 하였다.

\section{결 과}

\section{1. 초산 아연 포르말린 고정액과 $5 \%$ 질산, $\mathrm{TBD}-1,5 \% \mathrm{EDTA}$, $10 \%$ EDTA, Tris/EDTA 탈회액을 사용한 1단계 결과}

골수생검조직을 초산 아연 포르말린 고정액과 $5 \%$ 질산, TBD-1, $5 \% \mathrm{EDTA}, 10 \% \mathrm{EDTA}$, Tris/EDTA 탈회액에 넣은 후 고정 및 탈회시 간을 4/4시간, 24/8시간, 24/32시간, 24/48시간에서 실험하였다. 고정액으로 사용한 초산 아연 포르말린 고정액은 박절 용이성은 용 이하나 $\mathrm{EBV}$ 동소교잡반응, C-MYC 형광동소교잡반응, $\mathrm{DNA}$ 중합 효소연쇄반응 검사의 검체로는 부적합한 것으로 나타났다(Table 3). 산 포함 고정액은 골수조직 내 세포의 $\mathrm{DNA}$ 를 파괴하는 것으로 판단되었다. 개선방향으로 산 포함 고정액을 산 비포함 고정액으로 교체하였다. 고정시간에서 4 시간, 고정 및 탈회시간에서 4/4시간, 고정 및 탈회 시 $37^{\circ} \mathrm{C}$ 의 조건은 실험에서 큰 의미가 없는 것으로 나 타나 제외하였다.

\section{2. $10 \%$ 포르말린 고정액과 $5 \%$ 질산, TBD-1, 5\% EDTA, $10 \%$ EDTA, Tris/EDTA 탈회액을 사용한 2단계 결과}

골수생검조직을 $10 \%$ 포르말린 고정액과 $5 \%$ 질산, TBD- $1,5 \%$ $\mathrm{EDTA}, 10 \% \mathrm{EDTA}$, Tris/EDTA 탈회액에 넣은 후 고정 및 탈회시간 을 24/8시간, 24/32시간, 24/48시간에서 실험하였다. $10 \%$ 포르 말린 고정액으로 교체한 후 각각의 검사에서 호전되었으나 검체에 적용하기에는 미흡하였다. 산성 탈회액 역시 각각의 검사결과에 영 향을 주는 것으로 판단되었다(Table 4). 개선방향으로 고정액을 $10 \%$ 중성 완충 포르말린 고정액으로 교체하고, 탈회액 중 산성 탈 회액은 실험에서 제외하였다. 고정 및 탈회시간은 24/32시간, 24/48시간으로 결정하였다.

\section{3. $10 \%$ 중성 완충 포르말린 고정액과 $5 \% \mathrm{EDTA}, 10 \% \mathrm{EDTA}$, Tris/EDTA 탈회액을 사용한 3단계 결과}

골수 생검조직을 $10 \%$ 중성 완충 포르말린 고정액과 $5 \% \mathrm{EDTA}$, $10 \% \mathrm{EDTA}$, Tris/EDTA 탈회액에 넣은 후 고정 및 탈회시간을 24/32시간, 24/48시간에서 실험하였다. $10 \%$ 중성 완충 포르말린 고정액으로 고정한 후 $\mathrm{EDTA}$ 탈회액으로 탈회 시 각각의 검사에서 양호한 성적을 얻었다(Table 5). 개선방향으로 탈회액을 10\% $\mathrm{EDTA}$, Tris-EDTA 용액으로 결정하였다. 고정시간 및 탈회시간이 기존 처리시간보다 1 일이 늦어지는 점이 있었고, 조직이 딱딱해져 박절하기 어려운 점이 있으나 부족한 탈회시간을 보충하기 위하여 KOS rapid microwave tissue processor (Milestone Co., Sorisole, Italy) 기기 도입, 포매 방향, 박절 두께, 박절 기술 향상 등

Table 3. Decalcifying agent results in bone marrow biopsies fixed with acetic acid-zinc chloride formalin solution

\begin{tabular}{llccc}
\hline Decalcifying agent & Cutting & EBV ISH & C-MYC FISH & DNA PCR \\
\hline $5 \%$ nitric acid & Easy & Poor & Poor & Poor \\
TBD-1® & Easy & Poor & Poor & Poor \\
$5 \%$ EDTA & Difficult & Poor & Poor \\
$10 \%$ EDTA & Difficult & Poor & Poor & Poor \\
Tris/EDTA & Difficult & Poor & Poor & Poor \\
\hline
\end{tabular}

Abbreviation: EDTA, ethylenediamintetraacetic acid; EBV, epstein-barr virus; ISH, in situ hybridization; FISH, fluorescence in situ hybridization; DNA, deoxyribonucleic acid; PCR, polymerase chain reaction.

Table 4. Decalcifying agent results in bone marrow biopsies fixed with $10 \%$ formalin solution

\begin{tabular}{clccc}
\hline Decalcifying agent & Cutting & EBV ISH & C-MYC FISH & DNA PCR \\
\hline $5 \%$ nitric acid & Easy & Poor & Poor & Poor \\
TBD-1 $\mathrm{R}$ & Easy & Poor & Poor & Poor \\
$5 \%$ EDTA & Difficult & Good & Good & Good \\
$10 \%$ EDTA & Difficult & Good & Good & Good \\
Tris/EDTA & Difficult & Good & Good \\
\hline
\end{tabular}

See Table 3. 
Table 5. 5\% EDTA, 10\% EDTA, and Tris-EDTA decalcification results in bone marrow biopsies fixed with $10 \%$ neutral buffered formalin solution

\begin{tabular}{cllll}
\hline Decalcifying agent & Cutting & EBV ISH & C-MYC FISH & DNA PCR \\
\hline $5 \%$ EDTA & Difficult & Excellent & Good & Good \\
$10 \%$ EDTA & Easy & Excellent & Excellent & Excellent \\
Tris/EDTA & Easy & Excellent & Excellent & Excellent \\
\hline
\end{tabular}

See Table 3.

Table 6. 10\% EDTA and Tris-EDTA decalcification results in bone marrow biopsies fixed with 10\% neutral buffered formalin solution

\begin{tabular}{ccccc}
\hline Decalcifying agent & Cutting & EBV ISH & C-MYC FISH & DNA PCR \\
\hline $10 \%$ EDTA & Excellent & Excellent & Excellent & Excellent \\
Tris/EDTA & Excellent & Excellent & Excellent & Excellent \\
\hline
\end{tabular}

See Table 3.
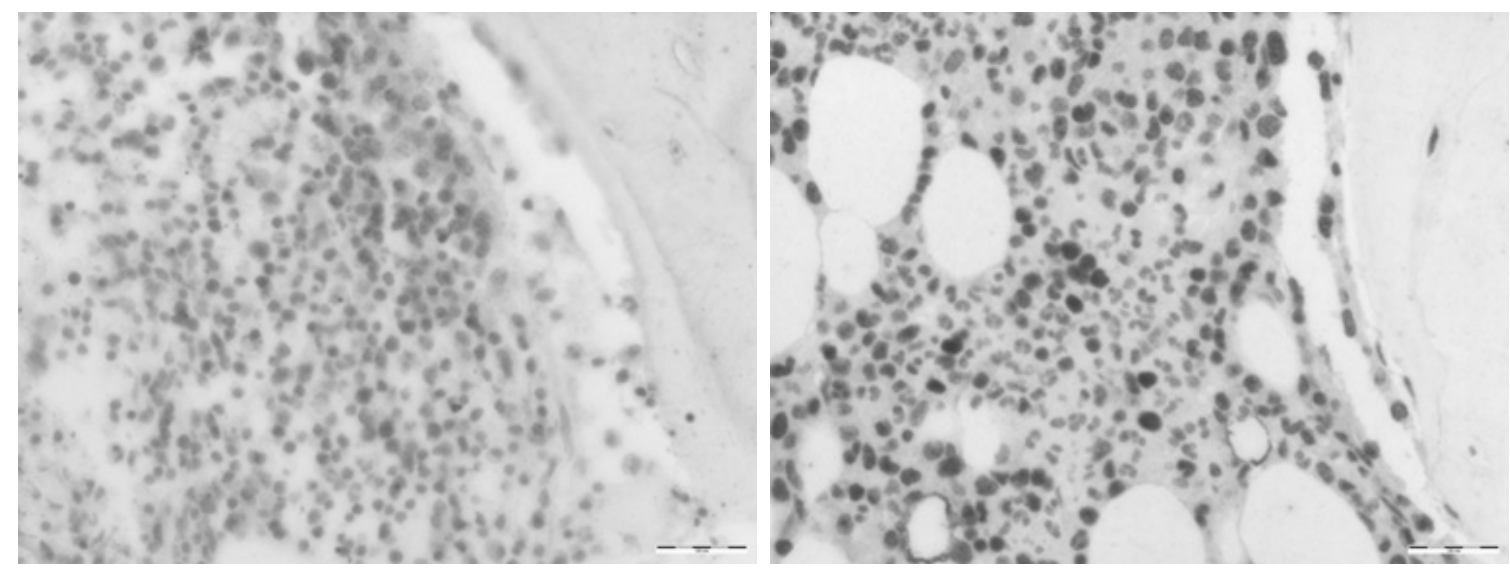

Fig. 1. Effect of EBV-ISH by $5 \%$ nitric acid decalcification in bone marrow biopsies fixed with $10 \%$ formalin solution (Lt \& RT, x100).

으로 해결하고자 하였다.

\section{4. $10 \%$ 중성 완충 포르말린 고정액과 $10 \%$ EDTA, Tris-EDTA 탈회액을 사용한 최종 결과}

$10 \%$ 중성 완충 포르말린 용액과 $10 \%$ EDTA, Tris-EDTA 용액에 넣은 후 고정 및 탈회시간을 24/32시간(32시간 탈회 중 6시간은 탈 회기 사용)에서 실험하였다. 조직절편은 기존 $2 \sim 3 \mu \mathrm{m}$ 두께에서 $1 \sim 2 \mu \mathrm{m}$ 두께로 조정하고, hematoxylin \& eosin 염색 시 hematoxylin에 의한 핵 염색 시간을 기존 3 분에서 1 분으로 조정하였다. $10 \%$ 중성 완충 포르말린 용액으로 고정한 후 EDTA 용액으로 탈회 시 각각의 검사에서 양호한 성적을 보였다(Table 6).

\section{5. 면역 및 분자병리검사를 사용한 적합성 평가 결과}

1) $\mathrm{EBV}$ 동소교잡반응

$\mathrm{EBV}$ 동소교잡반응의 경우 $10 \%$ 포르말린 고정액과 $5 \%$ 질산 탈 회액으로 처리한 검체에서는 위양성이 많이 나타났고(Fig. 1), 10\%
중성 완충 포르말린 고정액과 $10 \% \mathrm{EDTA}$ 탈회액에서 고정 및 탈회 를 실시한 검체에서는 위양성이 확연하게 줄어들었으며(Fig. 2) 미 세하지만 $10 \%$ 중성 완충 포르말린 고정액과 Tris-EDTA 탈회액에 서 조금 더 깨끗한 배경을 얻을 수 있었다(Fig. 3).

\section{2) C-MYC 형광동소교잡반응}

$\mathrm{C}-\mathrm{MYC}$ 형광동소교잡반응의 경우 $5 \%$ 질산 탈회액으로 처리한 검체는 형광신호정보(fluorescent signal)가 없는 반면에 5\% EDTA 탈회액으로 처리한 검체는 형광신호정보가 미세하게 보였다(Fig. 4). $10 \% \mathrm{EDTA}$ 와 Tris-EDTA 탈회액으로 처리한 검체는 형광신호 정보가 $5 \% \mathrm{EDTA}$ 탈회액으로 처리한 검체보다 더 뚜렷해진 형광신 호정보를 볼 수 있었다(Fig. 5).

\section{3) DNA 중합효소연쇄반응}

$\mathrm{DNA}$ 중합효소연쇄반응의 경우 5\% 질산 탈회액으로 처리한 검 체에서는 염색대가 나타 나지 않았다. $5 \%$ EDTA 탈회액으로 처리 


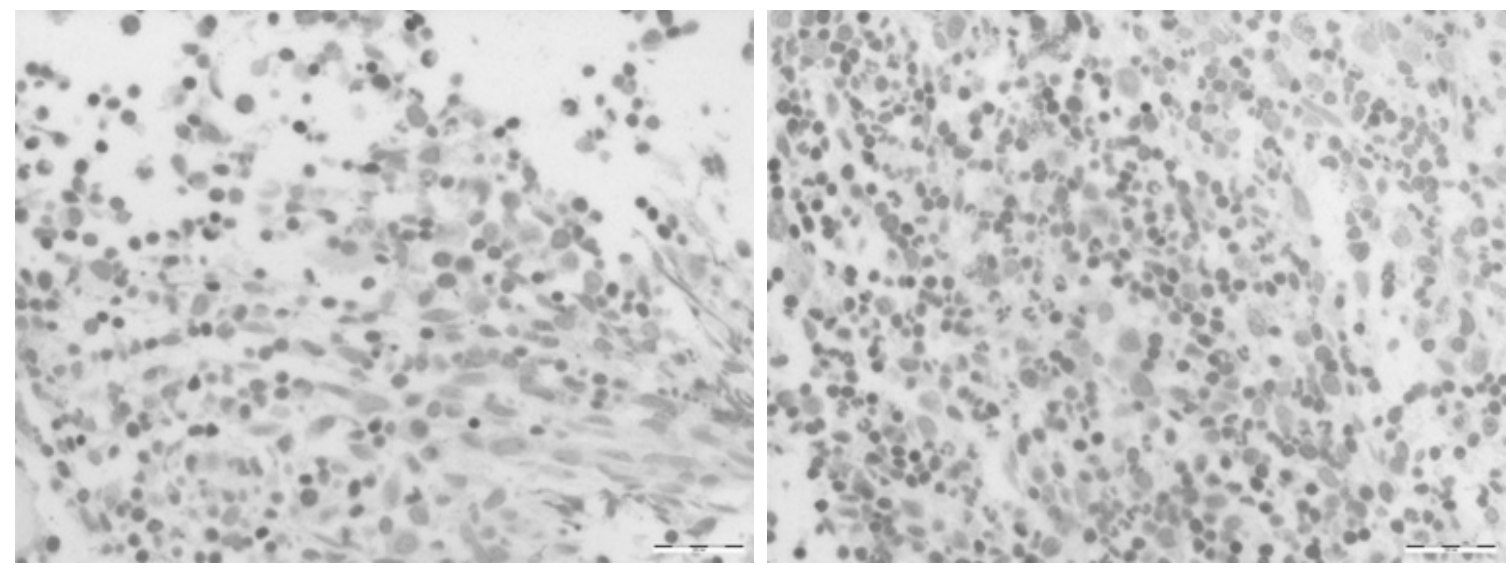

Fig. 2. Effect of EBV ISH by $5 \%$ nitric acid decalcification in bone marrow biopsies fixed with $10 \%$ neutral buffered formalin solution (Lt \& RT, x100).
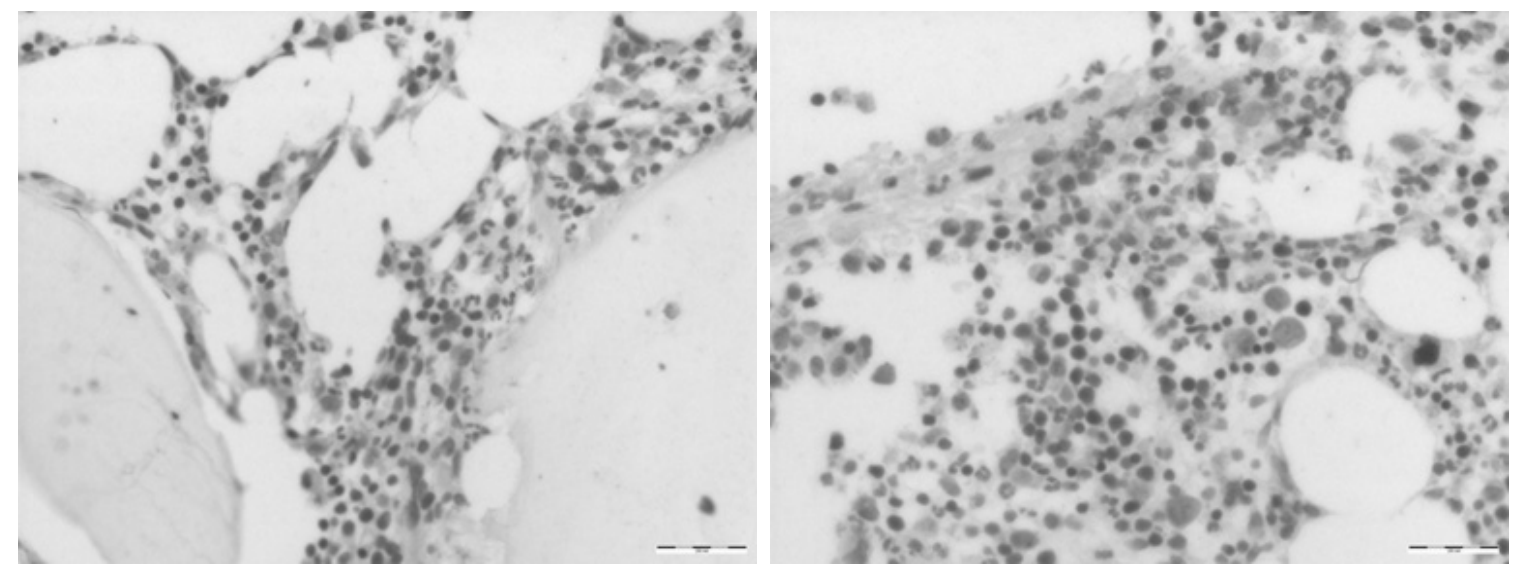

Fig. 3. Effect of EBV-ISH by Tris-EDTA (pH 9.0) decalcification in bone marrow biopsies fixed with $10 \%$ neutral buffered formalin solution (Lt \& RT, x100).
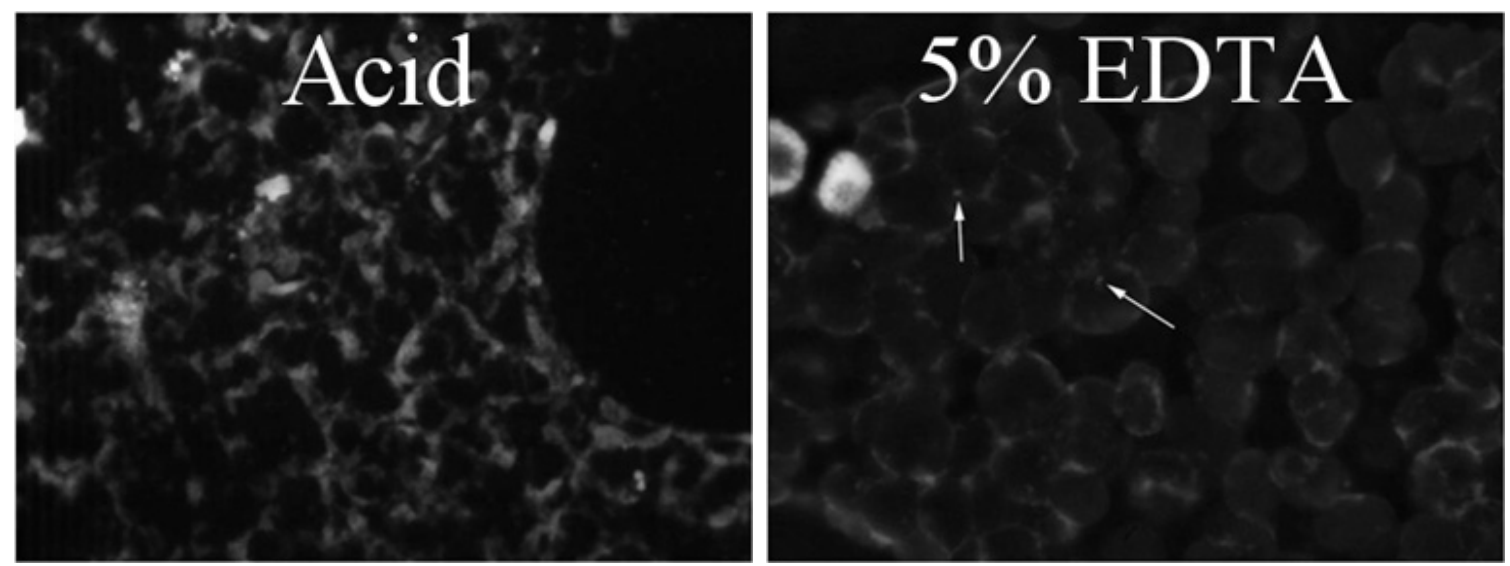

Fig. 4. Effect of C-MYC FISH by 5\% nitric acid and 5\% EDTA (pH 8.0) decalcification in bone marrow biopsies (Lt \& Rt x400).

한 검체에서는 대조군과 비교 해봤을 때 희미한 염색 대를 볼수 있 었고(Fig. 6), 10\% EDTA 탈회액과 Tris-EDTA 탈회액에서 처리한 4) RNA 질 평가 결과 검체에서는 뚜렷한 염색대를 볼 수 있었다(Fig. 7).

$10 \%$ 중성 완충 포르말린 용액과 10\% 질산 용액, $10 \%$ 중성 완충 

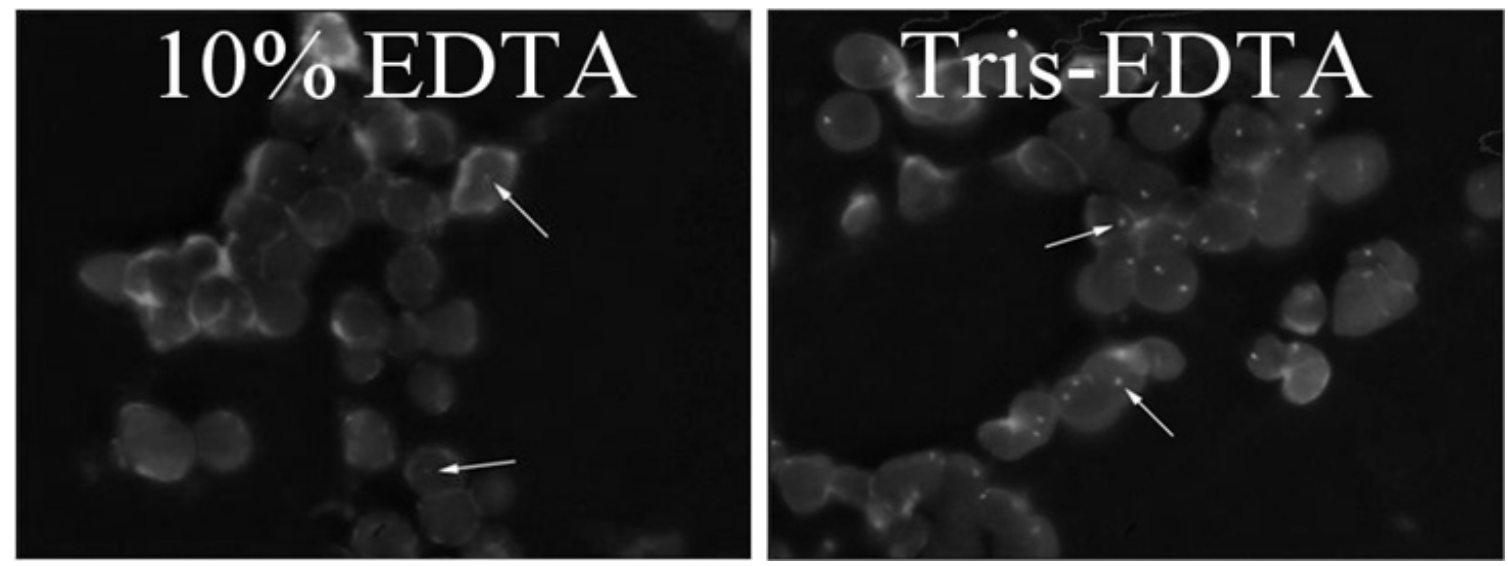

Fig. 5. Effect of C-MYC FISH by 10\% EDTA ( $\mathrm{pH}$ 8.0) and Tris-EDTA (pH 9.0) decalcification in bone marrow biopsies (Lt \& Rt, x400).

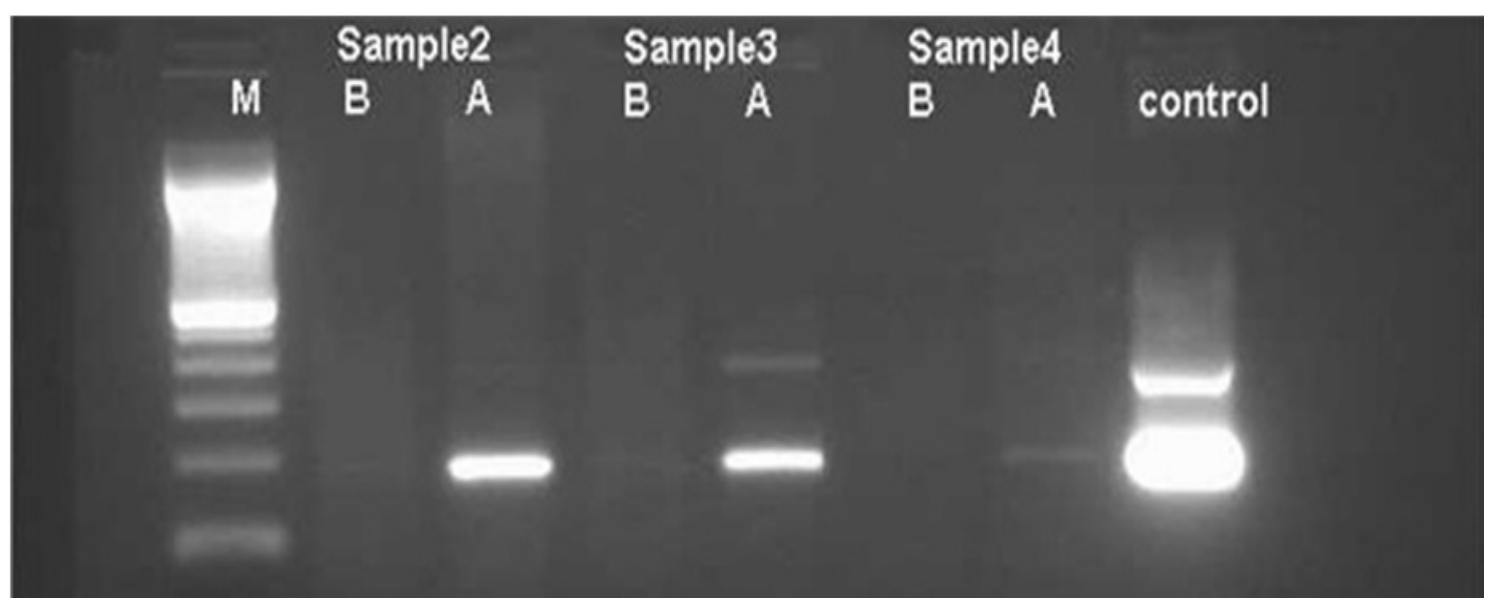

Fig. 6. Effect of DNA PCR by 5\% nitric acid (sample B) and 5\% EDTA (sample A) decalcification in bone marrow biopsies.

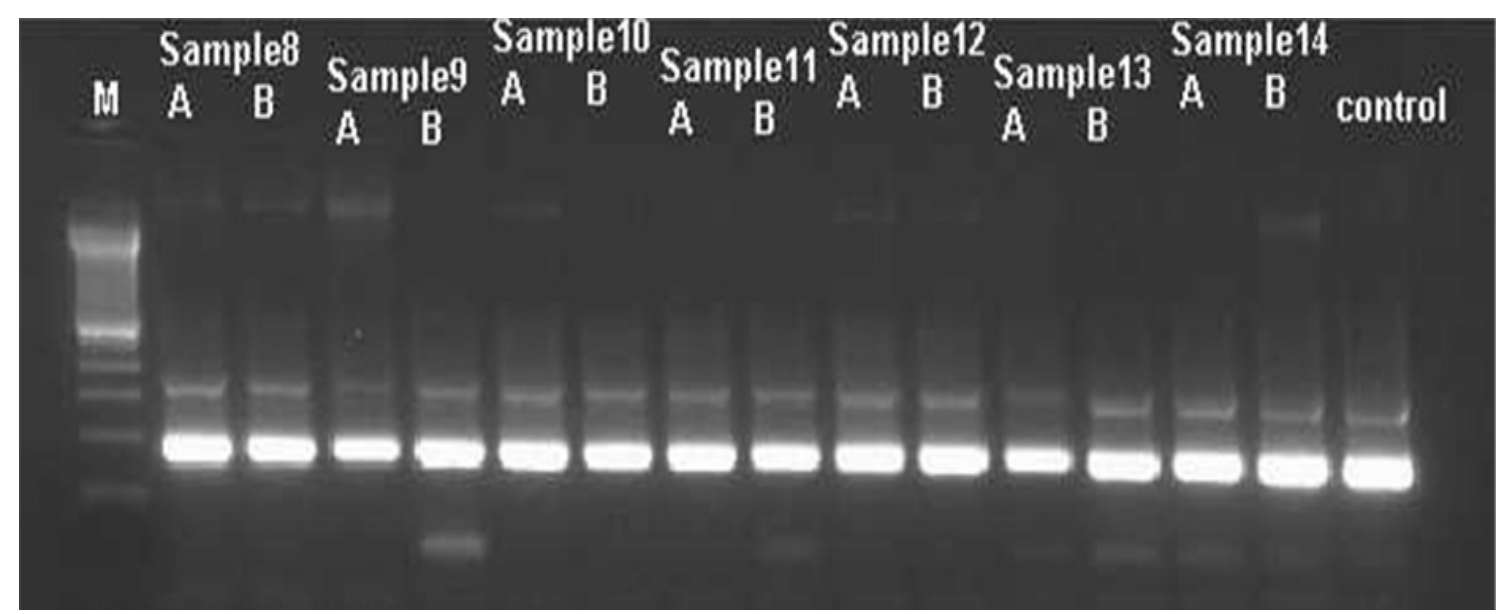

Fig. 7. Effect of DNA PCR by $10 \%$ EDTA (sample B) and Tris-EDTA (sample A) decalcification in bone marrow biopsies.

포르말린 용액과 $10 \% \mathrm{EDTA}$ 용액, $10 \%$ 중성 완충 포르말린 용액과 Tris-EDTA 용액에 넣은 후 고정 및 탈회시간을 24/32시간에서 실 험하였다. $10 \%$ 질산용액을 사용한 검체를 제외한 다른 검체에서
비교적 양질의 RNA를 추출할 수 있었다. RNA 실시간 연쇄 중합반 응 검사의 경우 $10 \%$ 포르말린 고정액과 $5 \%$ 질산 탈회액으로 처리 한 검체의 RNA 양은 $29.2 \mathrm{ng} / \mu \mathrm{L}, 31.5 \mathrm{ng} / \mu \mathrm{L}$ 로 나타났으며 
Table 7. Difference of RNA isolation rate according to decalcification solutions

\begin{tabular}{cccc}
\hline $\begin{array}{c}\text { Decalcifying } \\
\text { agent }\end{array}$ & $\begin{array}{c}\text { Sample } \\
\text { number }\end{array}$ & $\begin{array}{c}\text { RNA concen- } \\
\text { tration }(\mathrm{ng} / \mu \mathrm{L})\end{array}$ & $\begin{array}{c}260 / 280 \\
\text { ratio }\end{array}$ \\
\hline 10\% formalin/ & $\mathrm{S} 1$ & 78.5 & 1.62 \\
$5 \%$ nitric acid & $\mathrm{S} 2$ & 29.2 & 1.54 \\
& $\mathrm{~S} 3$ & 31.5 & 1.48 \\
$10 \% \mathrm{NBF} /$ & $\mathrm{S} 4$ & 226.2 & 1.78 \\
$10 \% \mathrm{EDTA}$ & $\mathrm{S} 5$ & 275.6 & 1.81 \\
& $\mathrm{~S} 6$ & 140.7 & 1.78 \\
$10 \% \mathrm{NBF} /$ & $\mathrm{S} 7$ & 112.5 & 1.86 \\
Tris-EDTA & $\mathrm{S} 8$ & 136.8 & 1.86 \\
& $\mathrm{~S} 9$ & $1,106.7$ & 1.86 \\
\hline
\end{tabular}

Abbreviation: NBF, neutral buffered formalin; EDTA, ethylenediamineteraacetic acid; RNA, ribonucleic acid.

$260 / 280$ 비는 각각 $1.62,1.54,1.48$ 로 나왔다. $10 \%$ 중성 완충 포 르말린 고정액과 $10 \% \mathrm{EDTA}$ 탈회액으로 처리한 검체의 $\mathrm{RNA}$ 양은 각각 $226.2 \mathrm{ng} / \mu \mathrm{L}, 275.6 \mathrm{ng} / \mu \mathrm{L}$ 으로 나타났으며 260/280 비는 각 각 $1.78,1.81$ 로 나왔다. $10 \%$ 중성 완충 포르말린 고정액과 Tris$\mathrm{EDTA}$ 탈회액으로 처리한 검체의 RNA양은 각각 $112.5 \mathrm{ng} / \mu \mathrm{L}$, $136.8 \mathrm{ng} / \mu \mathrm{L}$ 로 나타났으며 260/280 비는 모두 1.86으로 나왔다 (Table 7).

\section{고 찰}

골수생검조직검사에서 각종 탈회액의 특징을 이해하여 목적에 맞는 용액을 선택하고, 탈회로 인한 인공물(artifact)을 최소화하는 것이 중요하다(Lee 등, 1993; Naresh 등, 2006; Castania 등, 2015; Choi 등, 2015). 탈회를 사용한지 100년 이상 지난 지금도, 탈회방법을 개선하기 위해 많은 매뉴얼과 논문이 발표되고 있다 (Lim, 1991; Choi, 1992; Callis와 Sterchi, 1998; Kim 등 2005). 최근 연구 발표에 의하면 골수생검조직으로 분자병리검사 시 행 시 분석이 불가능하거나 재현성이 떨어지는 것은 고정액이나 탈회액 의 조성 성분 중 산 으로 인한 조직 내의 DNA 손상, 파괴가 주요 원 인이며, $\mathrm{EDTA}$ 계열 탈회액을 사용한 경우 핵산의 양과 질에서 상당 한 개선 효과가 있다고 보고하였다(Alers 등, 1999; Brown 등, 2002; Reineke 등, 2006; Singh 등, 2013; Choi 등, 2015).

본 연구에서는 탈회과정에서 나타날 수 있는 단점을 극복하고, 고정액 및 탈회액의 종류와 고정시간과 탈회시간의 적정조건을 구 하기 위해 실험을 진행해 보았다. 그 결과 산이 포함된 고정액 및 산 성 탈회액을 사용하였을 경우 $\mathrm{EBV}$ 동소교잡반응 검사에서는 비특 이적 반응이 일어나서 진단에 사용할 수 없었으며, C-MYC 형광동 소교잡반응 검사에는 정상군이 발현이 되지 않았다. 또한 $\mathrm{DNA}$ 와 $\mathrm{RNA}$ 추출 후 농도 측정과 $\mathrm{DNA}$ 중합효소연쇄반응, RNA 실시간 연
쇄 중합반응 검사를 수행한 결과 추출된 핵산의 양과 질이 검사에 이용할 수 없을 정도로 불량하였다. 그러나 $10 \%$ 중성 완충 포르말 린 고정액으로 사용하고 $\mathrm{EDTA}$ 계열의 탈회액으로 처리한 검체들 은 $\mathrm{EBV}$ 동소교잡반응 검사에서 비특이적 반응이 없어졌고, $\mathrm{C}-\mathrm{MYC}$ 형광동소교잡반응 검사에서는 정상군이 발현되었으며 $\mathrm{DNA}$ 중합효소연쇄반응과 RNA 실시간 연쇄 중합반응 검사에 적 합하게 나타났다.

$\mathrm{EDTA}$ 계열의 탈회액의 단점으로는 탈회시간이 오래 걸리며 파 라핀 블록 박절이 불량하고, hematoxylin \& eosin 염색에서 핵 염 색이 진한 것이 문제였다. 이런 단점들은 탈회기를 이용하여 탈회 시간을 보충하였고, 박절의 두께 조절, 그리고 hematoxylin \& eosin 염색 시 핵 염색시간을 단축하는 것으로 문제를 해결하였다. 고정액 선정, 탈회액 선정, 고정시간 24시간확보, 탈회시간 32시간 (탈회기 6시간 포함), 박절 두께 1 2 $\mu \mathrm{m}$, hematoxylin \& eosin 염 색 시 핵 염색시간 1 분으로 업무 표준화를 통해 골수생검조직의 고 정 및 탈회방법을 개선함으로써 ISH, FISH, DNA 검사뿐만 아니라 $\mathrm{RNA}$ 연구도 가능하며 각종 검사법의 민감도, 특이도, 재현성을 확 보할 수 있게 되었다.

$\mathrm{EBV} \mathrm{ISH} \mathrm{검사} \mathrm{시에} \mathrm{위양성이} \mathrm{없어져} \mathrm{한} \mathrm{두} \mathrm{개의} \mathrm{감염세포도} \mathrm{검출}$ 할 수 있게 되어 검사의 신뢰도가 높아졌으며, C-MYC 형광동소교 잡반응 검사에서는 형광신호정보가 현저하게 잘 보이게 되었다. 추 출된 DNA 및 RNA의 단위 세포당 양이 현저히 증가하였으며, 특히 $\mathrm{RNA}$ 실시간 연쇄 중합반응 검사를 성공적으로 수행할 수 있게 되 었다.

본 검체처리방법 개선으로 골수생검조직을 이용한 각종 검사법 의 안정화로 환자의 진단, 예후, 치료방침 결정에 기여 할 수 있게 되 었다. 본원에서 개선한 탈회 방법은 동일한 검사를 시행하는 의료 진들에게 검사 결과의 질을 향상시킬 수 있는 방법이 될 것으로 생 각된다. 또한 골수를 이용한 유전자 발현 연구를 하는 혈액종양내 과, 병리과, 진단검사의학과에서는 골수생검조직과 함께 다른 생 검조직으로도 연구를 할 수 있게 되어 이 분야의 연구발전에 크게 기여할 것으로 생각된다.

\section{요 약}

$10 \%$ 질산으로 탈회과정을 거친 골수생검조직에서는 각종 병리 검사가 불가능하거나 재현성이 극히 제한적이었다. 각 실험군의 고 정액으로는 산을 포함한 고정액과 산 비포함 고정액으로 나누어 사 용하고, 탈회액으로는 산성 탈회액과 알카리성 탈회액(EDTA계열) 으로 나누어 사용하였으며, 단계별 시간을 각각 다르게 하여 실험 하였다. 산이 포함된 고정액 및 탈회액을 사용하였을 경우 모든 병 
리검사가 불가능할 정도로 검체가 불량하였다. 그러나 $\mathrm{EDTA}$ 계열 의 탈회액으로 처리한 검체들은 EBV ISH에서는 비특이적 반응이 없어졌으며 FISH, DNA, RNA 검사에서도 병리진단이나 각종 연구 에 적합한 수준의 결과를 얻었다. 골수생검조직의 고정방법과 탈회 방법을 개선함으로써 ISH, FISH, DNA 검사뿐만 아니라 RNA 연구 도 가능하게 하며 각종 검사법의 민감도, 특이도 및 재현성을 확보 할 수 있게 되었다. 골수생검조직을 이용한 각종 검사법의 안정화 로 환자의 진단, 예후 예측 및 치료 방침결정에 기여 할 수 있을 것으 로 생각된다.

Acknowledgements: None

Funding: None

Conflict of interest: None

\section{References}

1. Alers JC, Krijtenburg PJ, Vissers KJ, van Dekken H. Effect of bone decalcification procedures on DNA in situ hybridization and comparative genomic hybridization: EDTA is highly preferable to a routinely used acid decalcifier. J Histochem Cytochem. 1999, 47(5):703-710.

2. Brown RS, Edwards J, Bartlett JW, Jones C, Dogan A. Routine acid decalcification of bone marrow samples can preserve DNA for FISH and CGH studies in metastatic prostate cancer. $J$ Histochem Cytochem. 2002, 50(1):113-115.

3. Callis G, Sterchi D. Decalcification of bone: Literature review and practical study of various decalcifying agents, methods, and their effects on bone histology. J Histotechnol. 1998, 21(1):49-58.

4. Castania VA, Silveira JW, Issy AC, Pitol DL, Castania ML, Neto $\mathrm{AD}$, et al. Advantages of a combined method of decalcification compared to EDTA. Microsc Res Tech. 2015, 78(2):111-118.

5. Choi SE, Hong SW, Yoon SO. Proposal of an appropriate decalcification method of bone marrow biopsy specimens in the era of expanding genetic molecular study. Journal of Pathology and
Translational Medicine. 2015, 49(3):236-242.

6. Choi YI. Influence of Decalcification on the Immunoreactivity of Paraffin Sections. Korean Journal of Medical Technologists. 1992, 24:90-100.

7. Cotelingam JD. Bone marrow biopsy: interpretive guidelines for the surgical pathologist. Adv Anat Pathol. 2003, 10(1):8-26.

8. Dimenstein IB. Bone grossing techniques: helpful hints and procedures. Annals of Diagnostic Pathology. 2008, 12(3):191198.

9. Kim SC, Back OU, Kim TJ, Bae HJ, Kang HG. Comparative research of decalcification methods for quick diagnosis on bone tissue. Korean J Clin Lab Sci. 2005, 37(1):47-55.

10. Korean Association of University Processors in Clinical Laboratory Science. Histotechnology. 2006, p40-41. Korea Medical Book. Seoul.

11. Lee SH, Erber WN, Portwit A, Tomonaga M, Peterson LS, ICSH guidelines for the standardization of bone marrow specimens and reports. Int J Lab Hematol. 2008, 30(5):349-364.

12. Lim HS. A Study on condition of decalcification solution in examination of marrow. Korean Journal of Medical Technologists. 1991, 23:139-148.

13. Naresh KN, Lampert I, Hasserjian R, Lykidis D, Elderfield K, Horncastle D, et al. Optimal processing of bone marrow trephine biopsy: the Hammersmith protocol. J Clin Pathol. 2006, 59(9):903-911.

14. Reineke T, Jenni B, Abdou MT, Frigerio S, Zubler P, Moch H, et al. Ultrasonic decalcification offers new perspectives for rapid FISH, DNA, and RT-PCR analysis in bone marrow trephines. Am J Surg Pathol. 2006, 30(7):892-896.

15. Sangeetha R, Uma K, Chandavarkar V. Comparison of routine decalcification methods with microwave decalcification of bone and teeth. J Oral Maxillofac Pathol. 2013, 17(3):386-391.

16. Singh VM, Salunga RC, Huang VJ, Tran Y, Erlander M, Plumlee $\mathrm{P}$, et al. Analysis of the effect of various decalcification agents on the quantity and quality of nucleic acid (DNA and RNA) recovered from bone biopsies. Ann Diagn Pathol. 2013, 17(4): 322-326.

17. Witter K, Matulova P, Misek I. The effects of two different decalcification procedures on size and structure of embryonic epithelial tissue in objects prepared for light microscopy. Anat Histol Embryol. 2001, 26(6):351-355. 